Synthesis of carbon-11-labeled isonicotinamides as new potential PET agents for imaging of GSK-3 enzyme in Alzheimer's disease

Mingzhang Gao, Min Wang, Qi-Huang Zheng<smiles>C[O+]c1ccncc1NC(=O)c1ccnc(NC(=O)C2CC2)c1</smiles>

$\left[{ }^{11} \mathrm{C}\right] \mathbf{4 a}$<smiles>C[O+]c1ccc(-c2ccncc2NC(=O)c2ccnc(NC(=O)C3CC3)c2)cc1</smiles>

$\left[{ }^{11} \mathrm{C}\right] 7 \mathrm{a}$

Carbon-11-labeled isonicotinamides 


\title{
Synthesis of carbon-11-labeled isonicotinamides as new potential PET agents for imaging of GSK-3 enzyme in Alzheimer's disease
}

\author{
Mingzhang Gao, Min Wang, Qi-Huang Zheng* \\ Department of Radiology and Imaging Sciences, Indiana University School of Medicine, 1345 West $16^{\text {th }}$ Street, Room 202, \\ Indianapolis, IN 46202, USA
}

*Corresponding author. Tel.: +1 317-278-4671. Fax: +1 317-278-9711. E-mail address: qzheng@iupui.edu.

This is where the receipt/accepted dates will go; Received Month XX, 2017; Accepted Month XX, 2017 [BMCL RECEIPT]

\begin{abstract}
The authentic standards 2-(cyclopropanecarboxamido)- $N$-(4-methoxypyridin-3-yl)isonicotinamide (4a) and 2(cyclopropanecarboxamido)- $N$-(4-(4-methoxyphenyl)pyridin-3-yl)isonicotinamide (7a), and their corresponding precursors 2(cyclopropanecarboxamido)- $N$-(4-hydroxypyridin-3-yl)isonicotinamide (4b) and 2-(cyclopropanecarboxamido)- $N$-(4-(4hydroxyphenyl)pyridin-3-yl)isonicotinamide (7b) were synthesized from methyl 2-aminoisonicotinate and cyclopropanecarbonyl chloride with overall chemical yield $47 \%$ in three steps, $22 \%$ in four steps, $40 \%$ in three steps, and $17 \%$ in four steps, respectively. The target tracers 2-(cyclopropanecarboxamido)- $N$-(4- $\left[{ }^{11} \mathrm{C}\right]$ methoxypyridin-3-yl)isonicotinamide $\left(\left[{ }^{11} \mathrm{C}\right] \mathbf{4 a}\right)$ and 2-(cyclopropanecarboxamido)- $N$-(4(4- $\left[{ }^{11} \mathrm{C}\right]$ methoxyphenyl)pyridin-3-yl)isonicotinamide $\left(\left[{ }^{11} \mathrm{C}\right] \mathbf{7 a}\right)$ were prepared from the precursors $(\mathbf{4 b}$ and $\mathbf{7 b})$ with $\left[{ }^{11} \mathrm{C}\right] \mathrm{CH} \mathrm{H}_{3} \mathrm{OTf}$ through $O-\left[{ }^{11} \mathrm{C}\right]$ methylation and isolated by HPLC combined with SPE in 40-50\% radiochemical yield, based on $\left[{ }^{11} \mathrm{C}\right] \mathrm{CO}_{2}$ and decay corrected to end of bombardment (EOB). The radiochemical purity was $>99 \%$, and the specific activity (SA) at EOB was $370-1110 \mathrm{GBq} / \mu \mathrm{mol}$ with a total synthesis time of $\sim 40$-minutes from EOB.
\end{abstract}

Keywords: Carbon-11-labeled isonicotinamides; Glycogen synthase kinase-3 (GSK-3); Radiosynthesis; Positron emission tomography (PET); Alzheimer's disease (AD).

Alzheimer's disease (AD) is the most common form of dementia and affects over 30 million people worldwide, and there are no reliable disease-modifying therapies at present. ${ }^{1-4}$ Currently, the cause of $\mathrm{AD}$ remains unclear and no any effective strategy is approved for preventing, curing and slowing the progress of $\mathrm{AD}^{5-7}$ To discover more effective treatments, a reliable diagnostic tool is really needed. ${ }^{8}$ Neuroimaging of $\mathrm{AD}$ is one of the most active as well as most challenging areas in neuroscience. ${ }^{9}$ Advanced biomedical imaging technique positron emission tomography (PET) is a promising modality for $\mathrm{AD}$, and significant advances have accomplished in this field of molecular imaging. ${ }^{10}$ The development of PET imaging probes for in vivo detection of Alzheimer's brains is critical for early and accurate diagnosis and for the successful discovery of disease-modifying therapies. ${ }^{11-13}$ Currently, aggregated $\beta$-amyloid plaques $(A \beta)$ and tau protein are two major biomarkers for $\mathrm{AD} .^{14,15}$ The representative $\mathrm{A} \beta$ PET tracers are $\left[{ }^{11} \mathrm{C}\right] \mathrm{PIB}{ }^{16}$ and $\left[{ }^{18} \mathrm{~F}\right]$ Amyvid (formerly known as $\left.\left[{ }^{18} \mathrm{~F}\right] \mathrm{AV}-45\right),{ }^{17}$ as displayed in Figure 1, the representative PET tau tracers include $\left[{ }^{11} \mathrm{C}\right] \mathrm{PBB}^{18}$ and $\left[{ }^{18} \mathrm{~F}\right] \mathrm{T} 807\left(\left[{ }^{18} \mathrm{~F}\right] \mathrm{AV}-1451\right){ }^{19}$ (Figure 1), and promising clinical PET imaging results with these tracers have been reported.

The success and limitations of $A \beta$ imaging and tau imaging have spurred efforts worldwide to develop new selective PET tracers for different imaging targets, and glycogen synthase kinase-3 (GSK-3) has become a novel and attractive molecular target for treatment and PET imaging of AD. ${ }^{20}$ The enzyme GSK-3 is a serine/threonine protein kinase, which exists as two isoforms GSK-3 $\alpha$ and GSK-3 $\beta$. GSK-3 plays an important role in a number of diverse cellular processes including metabolism, differentiation, proliferation, and 
apoptosis. Thus, GSK-3 is associated with a variety of diseases including $\mathrm{AD}$, type II diabetes, neurological disorders, and cancer. ${ }^{1}$ In our previous work, we and other have developed $\left[{ }^{11} \mathrm{C}\right] \mathrm{SB}-216763$ (GSK-3 $\beta / \alpha \mathrm{IC}_{50}$ (nM) $34.3 / 34.3$, Figure 1) as a PET GSK-3 imaging agent. $^{21,22}$ However, not very high in vitro binding affinity $\left(\mathrm{IC}_{50}\right)$ of SB-216763 and complicated two-step radiosynthesis of $\left[{ }^{11} \mathrm{C}\right] \mathrm{SB}-216763$ have motivated us to develop the new generation of GSK-3 PET probes. Recently, a new class of isonicotinamides was developed by Bristol-Myers Squibb (BMS) as highly selective, brain penetrable, and orally active GSK-3 inhibitors, and the representative compounds 2(cyclopropanecarboxamido)- $\mathrm{N}$-(4-methoxypyridin-3-

yl)isonicotinamide

(4a)

and

$2-$ (cyclopropanecarboxamido)- $N$-(4-(4-

methoxyphenyl)pyridin-3-yl)isonicotinamide

(7a)

showed appreciable inhibitory activity with GSK-3 $\beta / \alpha$ $\mathrm{IC}_{50}(\mathrm{nM}) \quad 3.4 / 4.5$ and $2.1 / 0.45$, respectively. ${ }^{1}$ In addition, both compounds $\mathbf{4 a}$ and $7 \mathbf{a}$ possess $O$-methyl position amenable to labeling with carbon-11 for onestep radiosynthesis. Here, we report the synthesis of carbon-11-labeled isonicotinamides (Figure 1) as new potential PET agents for imaging of GSK-3 enzyme in $\mathrm{AD}$.
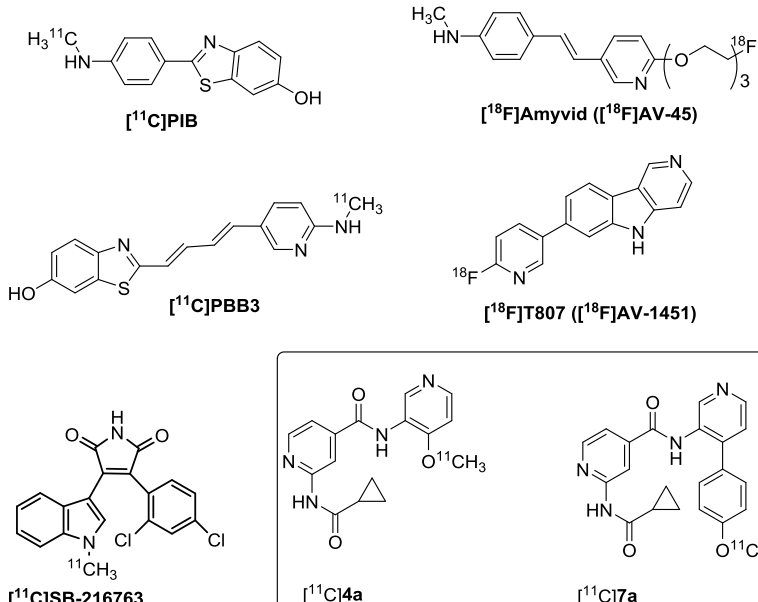

$\left[{ }^{11} \mathrm{C}\right] \mathbf{4 a}$

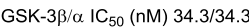

GSK-3 $\beta / \alpha / I_{50}(n M)$ 3.4/4.5 Carbon-11-labeled isonicotinamides

Figure 1. Chemical structure of $\left[{ }^{11} \mathrm{C}\right] \mathrm{PIB},\left[{ }^{18} \mathrm{~F}\right]$ Amyvid $\left(\left[{ }^{18} \mathrm{~F}\right] \mathrm{AV}-45\right)$, $\left[{ }^{11} \mathrm{C}\right] \mathrm{PBB} 3,\left[{ }^{18} \mathrm{~F}\right] \mathrm{T} 807\left(\left[{ }^{18} \mathrm{~F}\right] \mathrm{AV}-1451\right),\left[{ }^{11} \mathrm{C}\right] \mathrm{SB}-216763$ and carbon-11labeled isonicotinamides.

The synthesis of isonicotinamides $\mathbf{4 a}, \mathbf{b}$ is outlined in Scheme 1, according to the literature method ${ }^{1}$ with modifications. Commercial available starting material methyl 2-aminoisonicotinate was reacted with cyclopropanecarbonyl chloride to afford monoacylation intermediate 1 in $88 \%$ yield, through changing reaction solvent and controlling amount of acid chloride (1.1-1.2 equivalent), which was different from double acylation in literature. ${ }^{1}$ Subsequent treatment with $\mathrm{KOH}$ in methanol and water achieved complete conversion to acylated acid 2, which upon neutralization with aqueous $\mathrm{HCl}$ precipitated out as a white solid in $98 \%$ yield. The acid 2 could directly reacted 3-aminopyridines $\mathbf{3 a}, \mathbf{b}$ under corresponding amide formation conditions or be firstly converted to the acid chloride with oxalyl chloride then to react with 3-aminopyridines $\mathbf{3 a}, \mathbf{b}$, to give the product isonicotinamides $\mathbf{4 a}, \mathbf{b}$ in $55 \%$ and $46 \%$ yield, respectively.
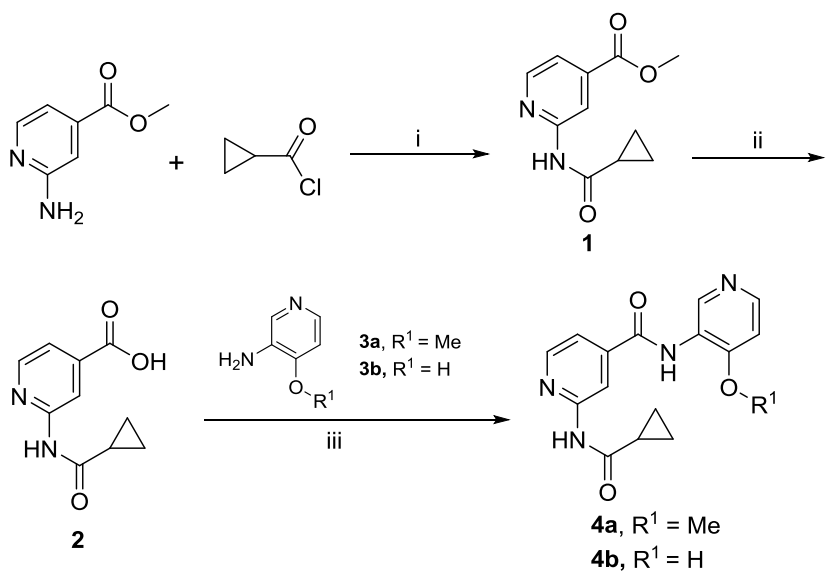

Scheme 1. Synthesis of isonicotinamides $\mathbf{4 a}, \mathbf{b}$. Reagents, conditions and yields: (i) pyridine, $0{ }^{\circ} \mathrm{C} ; 88 \%$. (ii) $\mathrm{KOH}, \mathrm{MeOH}, \mathrm{RT}$; $98 \%$. (iii) oxalyl chloride, DMF (cat.), RT; then 3-aminopyridines 3a,b, DIPEA, RT; 55\% and $46 \%$.

The synthesis of isonicotinamides $\mathbf{7 a}, \mathbf{b}$ is shown in Scheme 2, according to the literature method ${ }^{23}$ with modifications. The acid 2 reacted with 4-iodopyridin-3amine using same procedure as the synthesis of $\mathbf{4 a}, \mathbf{b}$ to obtain an intermediate $\mathbf{5}$ in $41 \%$ yield, which could be converted to the product $7 \mathbf{a}, \mathbf{b}$ by Suzuki coupling with aryl boronic acid or ester 6a,b in $63 \%$ and $48 \%$ yield, respectively.

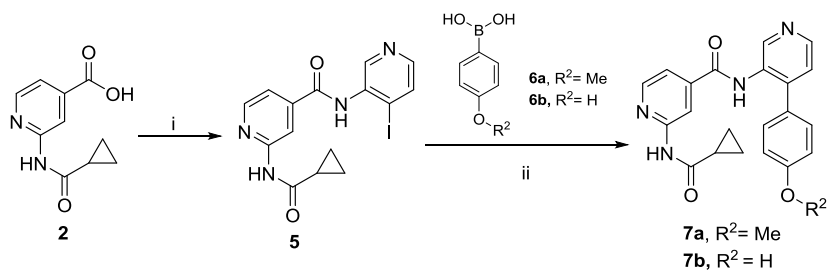

Scheme 2. Synthesis of isonicotinamides $\mathbf{7 a}, \mathbf{b}$. Reagents, conditions and yields: (i) oxalyl chloride, DMF (cat.), $0{ }^{\circ} \mathrm{C}$; then 4-iodopyridin-3-amine, DIPEA, $0{ }^{\circ} \mathrm{C}$ to RT; $41 \%$. (ii) $\mathrm{Na}_{2} \mathrm{CO}_{3}, \mathrm{Pd}\left(\mathrm{PPh}_{3}\right)_{4}$, dioxane, $110{ }^{\circ} \mathrm{C} ; 63 \%$ and $48 \%$.

Synthesis of carbon-11-labeled isonicotinamides $\left[{ }^{11} \mathrm{C}\right] \mathbf{4 a}$ and $\left[{ }^{11} \mathrm{C}\right] 7 \mathbf{a}$ is presented in Scheme 3. Isonicotinamides desmethyl precursor $\mathbf{4 b}$ or $\mathbf{7 b}$ underwent $O-\left[{ }^{11} \mathrm{C}\right]$ methylation ${ }^{24,25}$ using the reactive $\left[{ }^{11} \mathrm{C}\right]$ methylating agent $\left[{ }^{11} \mathrm{C}\right]$ methyl triflate $\left(\left[{ }^{11} \mathrm{C}\right] \mathrm{CH}_{3} \mathrm{OTf}\right)^{26,27}$ in acetonitrile at $80{ }^{\circ} \mathrm{C}$ under basic conditions $(2 \mathrm{~N} \mathrm{NaOH})$. The product was isolated by semi-preparative reverse-phase (RP) high performance liquid chromatography (HPLC) with a C-18 column, and then concentrated by solid-phase extraction (SPE) ${ }^{28-}$ 
${ }^{30}$ with a disposable C-18 Light Sep-Pak cartridge to produce the corresponding pure radiolabeled compound $\left[{ }^{11} \mathrm{C}\right] \mathbf{4 a}$ or $\left[{ }^{11} \mathrm{C}\right] 7 \mathbf{a}$ in $40-50 \%$ radiochemical yield, decay corrected to end of bombardment (EOB), based on $\left[{ }^{11} \mathrm{C}\right] \mathrm{CO}_{2}$.
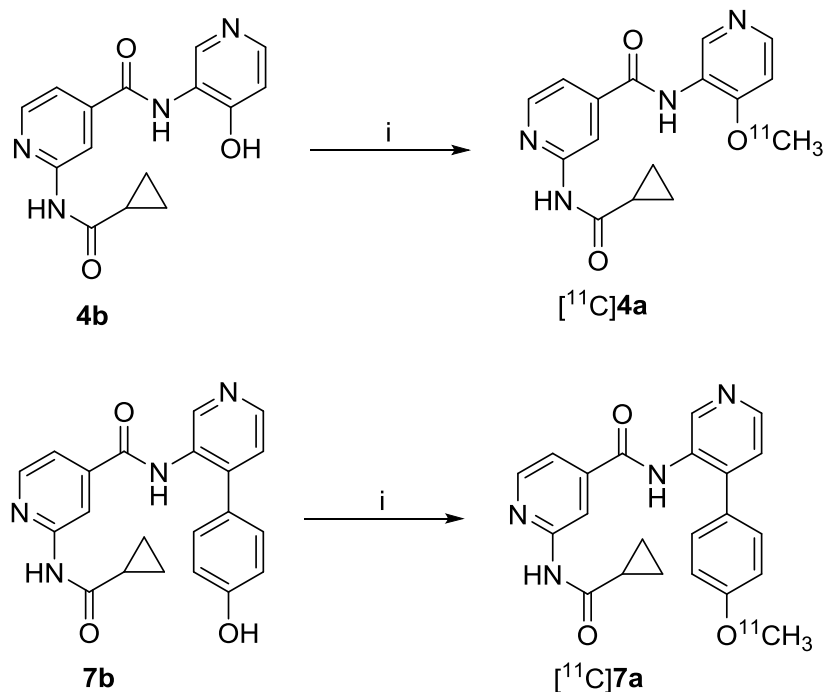

Scheme 3. Synthesis of carbon-11-labeled isonicotinamides $\left[{ }^{11} \mathrm{C}\right] \mathbf{4 a}$ and $\left[{ }^{11} \mathrm{C}\right] 7 \mathbf{a}$. Reagents, conditions and yields: (i) $\left[{ }^{11} \mathrm{C}\right] \mathrm{CH}_{3} \mathrm{OTf}, \mathrm{CH}_{3} \mathrm{CN}, 2 \mathrm{~N}$ $\mathrm{NaOH}, 80^{\circ} \mathrm{C}, 3 \mathrm{~min}$; HPLC-SPE; 40-50\%.

The radiosynthesis included three stages: 1) labeling reaction; 2) purification; and 3) formulation. We employed more reactive $\left[{ }^{11} \mathrm{C}\right] \mathrm{CH}_{3} \mathrm{OTf}$, instead of commonly used $\left[{ }^{11} \mathrm{C}\right]$ methyl iodide $\left(\left[{ }^{11} \mathrm{C}\right] \mathrm{CH}_{3} \mathrm{I}\right),{ }^{31}$ in $O$ $\left[{ }^{11} \mathrm{C}\right]$ methylation to improve radiochemical yield of $\left[{ }^{11} \mathrm{C}\right] \mathbf{4 a}$ and $\left[{ }^{11} \mathrm{C}\right] \mathbf{7 a}$. We used an Eckert \& Ziegler Modular Lab C-11 Methyl Iodide/Triflate module to produce $\left[{ }^{11} \mathrm{C}\right]$ methylating agent either $\left[{ }^{11} \mathrm{C}\right] \mathrm{CH}_{3} \mathrm{OTf}$ or $\left[{ }^{11} \mathrm{C}\right] \mathrm{CH}_{3} \mathrm{I}\left(\left[{ }^{11} \mathrm{C}^{-} \mathrm{CH}_{3} \mathrm{Br}\right.\right.$ passed through a NaI column $)$. The direct comparison between $\left[{ }^{11} \mathrm{C} \mathrm{CH}_{3} \mathrm{OTf}\right.$ and $\left[{ }^{11} \mathrm{C}\right] \mathrm{CH}_{3} \mathrm{I}$ confirmed this result. The labeling reaction was conducted using a $\mathrm{V}$-vial method. Addition of aqueous $\mathrm{NaHCO}_{3}$ to quench the radiolabeling reaction and to dilute the radiolabeling mixture prior to the injection onto the semi-preparative HPLC column for purification gave better separation of $\left[{ }^{11} \mathrm{C}\right] \mathbf{4 a}$ or $\left[{ }^{11} \mathrm{C}\right] 7 \mathbf{a}$ from its pyridinyl hydroxyl precursor $\mathbf{4 b}$ or phenyl hydroxyl precursor $\mathbf{7 b}$. We used Sep-Pak trap/release method instead of rotatory evaporation for formulation to improve the chemical purity of radiolabeled products $\left[{ }^{11} \mathrm{C}\right] \mathbf{4 a}$ and $\left[{ }^{11} \mathrm{C}\right] 7 \mathbf{a}$. In addition, a C18 Light Sep-Pak to replace a $\mathrm{C} 18$ Plus Sep-Pak allowed final product formulation with $\leq 5 \%$ ethanol. ${ }^{32}$ Overall, it took $\sim 40$ min for synthesis, purification and dose formulation.

The radiosynthesis was performed in a home-built automated multi-purpose $\quad\left[{ }^{11} \mathrm{C}\right]$-radiosynthesis module. ${ }^{33-35}$ This radiosynthesis module facilitated the overall design of the reaction, purification and reformulation capabilities in a fashion suitable for adaptation to preparation of human doses. In addition, the module is designed to allow in-process measurement of $\left[{ }^{11} \mathrm{C}\right]$-tracer specific activity (SA, GBq/ $\mu$ mol at EOB) using a radiation detector at the outlet of the HPLCportion of the system. For the reported syntheses, product SA was in a range of $370-1110 \mathrm{GBq} / \mu \mathrm{mol}$ at EOB. The factors that affect the EOB SA significantly to lead to such a wide range from 370 to 1110 $\mathrm{GBq} / \mu \mathrm{mol}$ are mainly from two parts: (1) carrier from the $\left[{ }^{11} \mathrm{C}\right]$-target, and (2) carrier from the $\left[{ }^{11} \mathrm{C}\right]$ radiosynthesis unit. ${ }^{36,37}$ We have optimized the $\left[{ }^{11} \mathrm{C}\right]$ gas irradiation target system and the $\left[{ }^{11} \mathrm{C}\right]$-radiosynthesis unit to eliminate ${ }^{12} \mathrm{C}$ carrier-added as much as possible and to reach the high end of the SA. To help produce high SA $\left[{ }^{11} \mathrm{C}_{\mathrm{CO}_{2}}\right.$, we usually do 10 -minute target preburn for 2-3 times, with the same beam current, prior to the actual production run. These pre-burn warm up the cyclotron target and eliminate significant amount of ${ }^{12} \mathrm{C}$ carrier in the cyclotron's $\left[{ }^{11} \mathrm{C}\right]$ gas target. Our Eckert \& Ziegler Modular Lab C-11 Methyl Iodide/Triflate module produces $\left[{ }^{11} \mathrm{C}\right] \mathrm{CH}_{3} \mathrm{OTf}$, convenient gas phase bromination of $\left[{ }^{11} \mathrm{C}\right]$ methane, and production of $\left[{ }^{11} \mathrm{C}_{\mathrm{CH}_{3}} \mathrm{OTf}\right.$. This 'dry' method, using $\mathrm{Br}_{2}$ to generate a $\left[{ }^{11} \mathrm{C}\right] \mathrm{CH}_{3} \mathrm{Br}$ intermediate, differs from other 'dry' method using $\mathrm{I}_{2}$ and 'wet' method using $\mathrm{LiAlH}_{4}$ and $\mathrm{HI}$, and seems to help minimize introduction of additional ${ }^{12} \mathrm{C}$ carrier after $\left[{ }^{11} \mathrm{C}\right] \mathrm{CO}_{2}$ production. ${ }^{27}$ To further help produce high SA $\left[{ }^{11} \mathrm{C}\right] \mathrm{CH}_{3} \mathrm{OTf}$, we usually do 2 'test loop' procedures when we set up the module for the actual $\left[{ }^{11} \mathrm{C}_{\mathrm{CH}_{3}} \mathrm{OTf}\right.$ production run and 1 actual $\left[{ }^{11} \mathrm{C}_{\mathrm{CH}_{3} \mathrm{OTf}}\right.$ production run before we do $\left[{ }^{11} \mathrm{C}\right]$ methylation labeling reaction. These procedures avoid any leak in the module to introduce additional ${ }^{12} \mathrm{C}$ carrier and eliminate significant amount of original ${ }^{12} \mathrm{C}$ carrier accumulated in the $\left[{ }^{11} \mathrm{C}\right] \mathrm{CH}_{3} \mathrm{OTf}$ production system. Therefore, the SA of our $\left[{ }^{11} \mathrm{C}\right]$-tracers is significantly improved. At the end of synthesis (EOS), the SA of $\left[{ }^{11} \mathrm{C}\right]$-tracer was determined again by analytical HPLC ${ }^{38}$ calculated, decay corrected to EOB, and based on $\left[{ }^{11} \mathrm{C}\right] \mathrm{CO}_{2}$, which was in agreement with the 'on line' determined value. In each our $\left[{ }^{11} \mathrm{C}\right]$-tracer production, if semi-preparative HPLC was used for purification, then the SA of $\left[{ }^{11} \mathrm{C}\right]$-tracer was assessed by both semi-preparative HPLC (during synthesis) and analytical HPLC (EOS); if SPE was used for purification, then the SA of $\left[{ }^{11} \mathrm{C}\right]$-tracer was only measured by analytical HPLC at EOS. ${ }^{25}$

Chemical purity and radiochemical purity were determined by analytical HPLC. ${ }^{38}$ The chemical purity of the precursors and reference standard was $>90 \%$. The radiochemical purity of the target tracer was $>99 \%$ determined by radio-HPLC through $\gamma$-ray (PIN diode) flow detector, and the chemical purity of the target tracer was $>90 \%$ determined by reversed-phase HPLC through UV flow detector. 
The experimental details and characterization data for compounds $\mathbf{1}, \mathbf{2}, \mathbf{4 a}, \mathbf{b}, \mathbf{5}$, and $\mathbf{7 a}, \mathbf{b}$ for the tracers $\left[{ }^{11} \mathrm{C}\right] \mathbf{4 a}$ and $\left[{ }^{11} \mathrm{C}\right] \mathbf{7} \mathbf{a}$ are given. ${ }^{39}$

In summary, synthetic routes with moderate to high yields have been developed to produce isonicotinamide precursors and reference standards, and carbon-11labeled isonicotinamides. The radiosynthesis employed $\left[{ }^{11} \mathrm{C}_{\mathrm{CH}_{3}} \mathrm{OTf}\right.$ for $\mathrm{O}-\left[{ }^{11} \mathrm{C}\right]$ methylation at the pyridinyl hydroxyl or phenyl hydroxyl position of the desmethyl precursor, followed by product purification and isolation using a semi-preparative RP HPLC combined with SPE. The carbon-11-labeled isonicotinamides were obtained in high radiochemical yield, radiochemical purity and chemical purity, with a reasonably short overall synthesis time, and high specific activity. This will facilitate studies to evaluate carbon-11-labeled isonicotinamides as new potential PET agents for imaging of GSK-3 enzyme in AD.

\section{Acknowledgments}

This work was partially supported by Indiana State Department of Health (ISDH) Indiana Spinal Cord \& Brain Injury Fund (ISDH EDS-A70-2-079612) in the United States. ${ }^{1} \mathrm{H}$ NMR and ${ }^{13} \mathrm{C}$ NMR spectra were recorded at 500 and $125 \mathrm{MHz}$, respectively, on a Bruker Avance II $500 \mathrm{MHz}$ NMR spectrometer in the Department of Chemistry and Chemical Biology at Indiana University Purdue University Indianapolis (IUPUI), which is supported by the United States National Science Foundation (NSF) Major Research Instrumentation Program (MRI) grant CHE-0619254.

\section{References and notes}

1. Luo, G.; Chen, L.; Burton, C. R.; Xiao, H.; Sivaprakasam, P.; Krause, C. M.; Cao, Y.; Liu, N.; Lippy, J.; Clarke, W. J.; Snow, K.; Raybon, J.; Arora, V.; Pokross, M.; Kish, K.; Lewis, H. A.; Langley, D. R.; Macor, J. E.; and Dubowchik, G. M. J. Med. Chem. 2016, 59, 1041.

2. Ariza, M.; Kolb, H. C.; Moechars, D.; Rombouts, F.; Andrés, J. I. J. Med. Chem. 2015, 58, 4365.

3. Watanabe, H.; Ono, M.; Saji, H. Scientific WorldJournal 2015, 2015, 124192.

4. James, O. G.; Doraiswamy, P. M.; Borges-Neto, S. Front. Neurol. 2015, 6, 38.

5. Adlard, P. A.; Tran, B. A.; Finkelstein, D. I.; Desmond, P. M.; Johnston, L. A.; Bush, A. I.; Egan, G. F. Front. Neurosci. 2014, 8, 327.

6. Jack, C. R. Jr. Radiology 2012, 263, 344.

7. Zimmer, E. R.; Leuzy, A.; Benedet, A. L.; Breitner, J.; Gauthier, S.; Rosa-Neto, P. J. Neuroinflammation 2014, $11,120$.
8. Catafau, A. M.; Bullich, S. Clin. Transl. Imaging 2015, 3, 39.

9. Villemagne, V. L.; Fodero-Tavoletti, M. T.; Masters, C. L.; Rowe, C. C. Lancet Neurol. 2015, 14, 114.

10. Sabri, O.; Seibyl, J.; Rowe, C.; Barthel, H. Clin. Transl. Imaging 2015, 3, 13.

11. Wurtman R. Metabolism 2015, 64(3 Suppl 1), S47.

12. Zimmer, E. R.; Leuzy, A.; Gauthier, S.; Rosa-Neto, P. Can. J. Neurol. Sci. 2014, 41, 547.

13. Ono, M. Chem. Pharm. Bull. 2009, 57, 1029.

14. Mach, R. H. J. Nucl. Med. 2015, 55, 1221.

15. Shah, M.; Catafau, A. M. J. Nucl. Med. 2014, 54, 871.

16. Klunk, W. E.; Engler, H.; Nordberg, A.; Bacskai, B. J.; Wang, Y.; Price, J. C.; Bergström, M.; Hyman, B. T.; Långström, B.; Mathis, C. A. Neuroimaging Clin. N. Am. 2003, 13, 781 .

17. Carpenter, A. P. Jr.; Pontecorvo, M. J.; Hefti, F. F.; Skovronsky, D. M. Q. J. Nucl. Med. Mol. Imaging 2009, 53, 387.

18. Maruyama, M.; Shimada, H.; Suhara, T.; Shinotoh, H.; Ji, B.; Maeda, J.; Zhang, M.-R.; Trojanowski, J. Q.; Lee, V. M.; Ono, M.; Masamoto, K.; Takano, H.; Sahara, N.; Iwata, N.; Okamura, N.; Furumoto, S.; Kudo, Y.; Chang, Q.; Saido, T. C.; Takashima, A.; Lewis, J.; Jang, M. K.; Aoki, I.; Ito, H.; Higuchi, M. Neuron 2013, 79, 1094.

19. Chien, D. T.; Bahri, S.; Szardenings, A. K.; Walsh, J. C.; Mu, F.; Su, M. Y.; Shankle, W. R.; Elizarov, A.; Kolb, H. C. J. Alzheimer's Dis. 2013, 34, 457.

20. Pandey, M. K.; DeGrado, T. R. Theranostics 2016, 6, 571.

21. Wang, M.; Gao, M.; Miller, K. D.; Sledge, G. W.; Hutchins, G. D.; Zheng, Q.-H. Bioorg. Med. Chem. Lett. 2011, 21, 245.

22. Li, L.; Shao, X.; Cole, E. L.; Ohnmacht, S. A.; Ferrari, V.; Hong, Y. T.; Williamson, D. J.; Fryer, T. D.; Quesada, C. A.; Sherman, P.; Riss, P. J.; Scott, P. J.; Aigbirhio, F. I. ACS Med. Chem. Lett. 2015, 6, 548.

23. Gao, M.; Wang, M.; Zheng, Q.-H. Bioorg. Med. Chem. Lett. 2015, 25, 2953.

24. Gao, M.; Wang, M.; Zheng, Q.-H. Bioorg. Med. Chem. Lett. 2016, 26, 1371.

25. Gao, M.; Wang, M.; Zheng, Q.-H. Bioorg. Med. Chem. Lett. 2016, 26, 3694.

26. Jewett, D. M. Int. J. Radiat. Appl. Instrum. A $\mathbf{1 9 9 2 ,}$ 43, 1383.

27. Mock, B. H.; Mulholland, G. K.; Vavrek, M. T. Nucl. Med. Biol. 1999, 26, 467.

28. Gao, M.; Wang, M.; Mock, B. H.; Glick-Wilson, B. E.; Yoder, K. K.; Hutchins, G. D.; Zheng, Q.-H. Appl. Radiat. Isot. 2010, 68, 1079.

29. Wang, M.; Gao, M.; Miller, K. D.; Zheng, Q.-H. Steroids 2011, 76, 1331.

30. Wang, M.; Gao, M.; Miller, K. D.; Sledge, G. W.; Zheng, Q.-H. Bioorg. Med. Chem. Lett. 2012, 22, 1569.

31. Allard, M.; Fouquet, E.; James, D.; Szlosek-Pinaudm, M. Curr. Med. Chem. 2008, 15, 235. 
32. Zheng, Q.-H.; Glick-Wilson, B.; Steele, B.; Shaffer, M.; Corbin, L.; Green, M. J. Labelled Compd. Radiopharm. 2015, 58, S392.

33. Mock, B. H.; Zheng, Q.-H.; DeGrado, T. R. J. Labelled Compd. Radiopharm. 2005, 48, S225.

34. Mock, B. H.; Glick-Wilson, B. E.; Zheng, Q.-H.; DeGrado, T. R. J. Labelled Compd. Radiopharm. 2005, 48, S224.

35. Wang, M.; Gao, M.; Zheng, Q.-H. Appl. Radiat. Isot. 2012, 70, 965 .

36. Gao, M.; Wang, M.; Green, M. A.; Hutchins, G. D.; Zheng, Q.-H. Bioorg. Med. Chem. Lett. 2015, 25, 1965.

37. Wang, M.; Gao, M.; Xu, Z.; Zheng, Q.-H. Bioorg. Med. Chem. Lett. 2015, 25, 4587.

38. Zheng, Q.-H.; Mock, B. H. Biomed. Chromatogr. 2005, 19, 671 .

39. (a). General: All commercial reagents and solvents were purchased from Sigma-Aldrich and Fisher Scientific, and used without further purification. $\left[{ }^{11} \mathrm{C}\right] \mathrm{CH}_{3} \mathrm{OTf}$ was prepared according to a literature procedure. $^{27}$ Melting points were determined on a MEL-TEMP II capillary tube apparatus and were uncorrected. ${ }^{1} \mathrm{H}$ and ${ }^{13} \mathrm{C}$ NMR spectra were recorded on a Bruker Avance II $500 \mathrm{MHz}$ NMR Fourier transform spectrometer at 500 and $125 \mathrm{MHz}$, respectively. Chemical shifts $(\delta)$ are reported in parts per million (ppm) relative to an internal standard tetramethylsilane (TMS, $\delta 0.0)\left({ }^{1} \mathrm{H}\right.$ NMR) and to the solvent signal $\left({ }^{13} \mathrm{C} \mathrm{NMR}\right)$, and coupling constants $(J)$ are reported in hertz $(\mathrm{Hz})$. Liquid chromatographymass spectra (LC-MS) analysis was performed on an Agilent system, consisting of an 1100 series HPLC connected to a diode array detector and a 1946D mass spectrometer configured for positive-ion/negative-ion electrospray ionization. The high resolution mass spectra (HRMS) were obtained using a Waters/Micromass LCT Classic spectrometer. Chromatographic solvent proportions are indicated as volume: volume ratio. Thin-layer chromatography (TLC) was run using Analtech silica gel GF uniplates $\left(5 \times 10 \mathrm{~cm}^{2}\right)$. Plates were visualized under UV light. Preparative TLC was run using Analtech silica gel UV254 plates $\left(20 \times 20 \mathrm{~cm}^{2}\right)$. Normal phase flash column chromatography was carried out on EM Science silica gel 60 (230-400 mesh) with a forced flow of the indicated solvent system in the proportions described below. All moisture- and air-sensitive reactions were performed under a positive pressure of nitrogen maintained by a direct line from a nitrogen source. Analytical RP HPLC was performed using a Prodigy (Phenomenex) $5 \mu \mathrm{m} \mathrm{C}-18$ column, $4.6 \times 250$ $\mathrm{mm}$; mobile phase $15 \% \mathrm{CH}_{3} \mathrm{CN} / 85 \% \mathrm{H}_{2} \mathrm{O} / 0.1 \%$ TFA for $\mathbf{4 a}, \mathbf{b}$ and $30 \% \mathrm{CH}_{3} \mathrm{CN} / 70 \% \quad 20 \mathrm{mM} \mathrm{H} \mathrm{HO}_{4}$ for $\mathbf{7 a}, \mathbf{b}$; flow rate $1.3 \mathrm{~mL} / \mathrm{min}$ for $\mathbf{4 a}, \mathbf{b}$ and $1.0 \mathrm{~mL} / \mathrm{min}$ for 7a,b; UV (254 nm) and $\gamma$-ray (PIN diode) flow detectors. Semi-preparative RP HPLC was performed using a Prodigy (Phenomenex) $5 \mu \mathrm{m} \mathrm{C}-18$ column, 10 $\times 250 \mathrm{~mm}$; mobile phase $15 \% \mathrm{CH}_{3} \mathrm{CN} / 85 \% \mathrm{H}_{2} \mathrm{O} / 0.1 \%$ TFA for $\mathbf{4 a}, \mathbf{b}$ and $30 \% \mathrm{CH}_{3} \mathrm{CN} / 70 \% 20 \mathrm{mM} \mathrm{H} \mathrm{HO}_{4}$ for $\mathbf{7 a}, \mathbf{b}$; flow rate $7 \mathrm{~mL} / \mathrm{min}$ for $\mathbf{4 a}, \mathbf{b}$ and $4 \mathrm{~mL} / \mathrm{min}$ for 7a,b; UV (254 nm) and $\gamma$-ray (PIN diode) flow detectors. C18 Light Sep-Pak cartridges were obtained from Waters Corporation (Milford, MA). Sterile Millex-FG $0.2 \mu \mathrm{m}$ filter units were obtained from Millipore Corporation (Bedford, MA).

(b). Methyl 2(cyclopropanecarboxamido)isonicotinate (1): To a solution of methyl 2-aminoisonicotinate (18.25 g, 120 mmol $)$ in pyridine $(200 \mathrm{~mL})$ was added cyclopropanecarbonyl chloride $(15.16 \mathrm{~g}, 145 \mathrm{mmol})$ at $0{ }^{\circ} \mathrm{C}$. After stirring at $0{ }^{\circ} \mathrm{C}$ for $3 \mathrm{~h}$, the reaction mixture was poured into cold $5 \mathrm{~N}$ aqueous $\mathrm{HCl}(500$ $\mathrm{mL}$ ) solution and stirred. The resulting precipitate was filtered, washed with cold water, and dried to give a white solid product $1(22.08 \mathrm{~g})$. The filtrate was extracted with EtOAc $(3 \times 100 \mathrm{~mL})$, washed with water, brine, dried over $\mathrm{Na}_{2} \mathrm{SO}_{4}$, and concentrated in vacuo, The residue was purified by column chromatography on silica gel with eluent (20:80 EtOAc/hexanes) to yield $1(1.15 \mathrm{~g})$. The two portion of solids were combined to give $1(23.23 \mathrm{~g}, 88 \%) . R_{f}=$ 0.68 (1:1 EtOAc/hexanes), mp 132-134 ${ }^{\circ} \mathrm{C} .{ }^{1} \mathrm{H}$ NMR $\left(\mathrm{CDCl}_{3}\right): \delta 0.90-0.95\left(\mathrm{~m}, 2 \mathrm{H}, \mathrm{CH}_{2}\right), 1.12-1.15(\mathrm{~m}, 2 \mathrm{H}$, $\left.\mathrm{CH}_{2}\right), 1.56-1.61(\mathrm{~m}, 1 \mathrm{H}, \mathrm{CH}), 3.93\left(\mathrm{~s}, 3 \mathrm{H}, \mathrm{OCH}_{3}\right)$, $7.58(\mathrm{~d}, J=5.0 \mathrm{~Hz}, 1 \mathrm{H}, \mathrm{Ar}-\mathrm{H}), 8.39(\mathrm{~d}, J=5.0 \mathrm{~Hz}$, $1 \mathrm{H}, \mathrm{Ar}-\mathrm{H}$ ), 8.56 (br s, $1 \mathrm{H}, \mathrm{CONH}$ ), 8.73 (s, 1H, ArH). MS (ESI): $221\left([\mathrm{M}+\mathrm{H}]^{+}, 100 \%\right)$; MS (ESI): 219 ([M-H] $\left.]^{-}, 1 \%\right)$.

(c). 2-(Cyclopropanecarboxamido)isonicotinic acid (2): $\mathrm{KOH}$ (14.52 g, $0.26 \mathrm{~mol}$ ) was added into the solution of compound $\mathbf{1}(16.2 \mathrm{~g}, 73.4 \mathrm{mmol})$ in methanol $(200 \mathrm{~mL})$ and water $(8 \mathrm{~mL})$. The reaction mixture was stirred at room temperature (RT) for $6 \mathrm{~h}$, then it was evaporated under reduced pressure. The residue was neutralized with $2 \mathrm{~N}$ aqueous $\mathrm{HCl}$. The resulting precipitate was filtered, and dried to give a white solid product $2(14.8 \mathrm{~g}, 98 \%) . R_{f}=0.18(1: 9$ $\mathrm{MeOH} / \mathrm{CH}_{2} \mathrm{Cl}_{2}$ ), mp 277-279 ${ }^{\circ} \mathrm{C}$. ${ }^{1} \mathrm{H}$ NMR (DMSO$\left.\mathrm{d}_{6}\right): \delta 0.82-0.83\left(\mathrm{~m}, 4 \mathrm{H}, 2 \times \mathrm{CH}_{2}\right), 2.00-2.05(\mathrm{~m}, 1 \mathrm{H}$, $\mathrm{CH}), 7.48(\mathrm{~d}, J=5.0 \mathrm{~Hz}, 1 \mathrm{H}, \mathrm{Ar}-\mathrm{H}), 8.45(\mathrm{~d}, J=5.0$ $\mathrm{Hz}, 1 \mathrm{H}, \mathrm{Ar}-\mathrm{H}), 8.56$ (s, 1H, CONH), 10.99 (1H, OH). MS (ESI): 207 ([M+H] $\left.]^{+}, 100 \%\right)$; MS (ESI): 205 ([M$\left.\mathrm{H}]^{-}, 15 \%\right)$.

(d). 2-(Cyclopropanecarboxamido)- $\mathrm{N}-(4-$ methoxypyridin-3-yl)isonicotinamide (4a): To a 250 $\mathrm{mL}$ flask was added compound 2 (206 mg, $1.0 \mathrm{mmol})$ in $\mathrm{CH}_{2} \mathrm{Cl}_{2}(20 \mathrm{~mL})$ to give a white suspension. After cooling to $0{ }^{\circ} \mathrm{C}$, oxalyl chloride $(0.3 \mathrm{~g})$ and DMF (2 drops) were added. The mixture was stirred at $0{ }^{\circ} \mathrm{C}$ for $1 \mathrm{~h}$, then the mixture was evaporated in vacuo. A solution of 4-methoxypyridin-3-amine (3a, $124 \mathrm{mg}$, $1.0 \mathrm{mmol})$ in $\mathrm{CH}_{2} \mathrm{Cl}_{2}(5 \mathrm{~mL})$ was added into above mixture at $0{ }^{\circ} \mathrm{C}$, followed by $N, N$ diisopropylethylamine (DIPEA, $260 \mathrm{mg}, 2.0 \mathrm{mmol}$ ). After stirring at RT for $2 \mathrm{~h}$, the reaction mixture was concentrated under reduced pressure to give a tan oil. 
The residue was purified by column chromatography on silica gel with eluent $\left(3: 97 \mathrm{MeOH} / \mathrm{CH}_{2} \mathrm{Cl}_{2}\right)$ to give a white solid product $4 \mathbf{a}(164 \mathrm{mg}, 55 \%) . R_{f}=0.69(1: 9$ $\left.\mathrm{MeOH} / \mathrm{CH}_{2} \mathrm{Cl}_{2}\right)$, mp 209-211 ${ }^{\circ} \mathrm{C} .{ }^{1} \mathrm{H}$ NMR $\left(\mathrm{CDCl}_{3}\right): \delta$ 0.93-0.97 (m, 2H, $\left.\mathrm{CH}_{2}\right), 1.12-1.15\left(\mathrm{~m}, 2 \mathrm{H}, \mathrm{CH}_{2}\right)$, 1.58-1.63 (m 1H, CH), $3.98\left(\mathrm{~s}, 3 \mathrm{H}, \mathrm{OCH}_{3}\right), 6.86(\mathrm{~d}, J$ $=5.5 \mathrm{~Hz}, 1 \mathrm{H}, \mathrm{Ar}-\mathrm{H}), 7.54(\mathrm{dd}, J=1.0,5.0 \mathrm{~Hz}, 1 \mathrm{H}$, Ar-H), 8.30 (s, 1H, Ar-H), 8.35 (d, $J=5.5 \mathrm{~Hz}, 1 \mathrm{H}, \mathrm{Ar}-$ $\mathrm{H}), 8.43(\mathrm{~d}, J=5.0 \mathrm{~Hz}, 1 \mathrm{H}, \mathrm{Ar}-\mathrm{H}), 8.44$ (s, 1H, Ar-H), 8.62 (s, 1H, NH), 9.53 (s, 1H, NH). MS (ESI): 313 $\left([\mathrm{M}+\mathrm{H}]^{+}, 100 \%\right)$; MS (ESI): $311\left([\mathrm{M}-\mathrm{H}]^{-}, 3 \%\right)$.

(e). 2-(Cyclopropanecarboxamido)- $\mathrm{N}-(4-$ hydroxypyridin-3-yl)isonicotinamide $(\mathbf{4 b})$ : Compound 4b was prepared using the same procedure as described for the synthesis of $\mathbf{4 a}$ by substituting 4hydroxypyridin-3-amine (3b) for $\mathbf{3 a}$ as a white solid, yield $46 \%$. $R_{f}=0.58\left(1: 9 \mathrm{MeOH} / \mathrm{CH}_{2} \mathrm{Cl}_{2}\right)$, mp 307$309{ }^{\circ} \mathrm{C}$. ${ }^{1} \mathrm{H}$ NMR (DMSO-d 6 ): $\delta 0.83-0.89(\mathrm{~m}, 4 \mathrm{H}, 2 \times$ $\mathrm{CH}_{2}$ ), 2.02-2.08 (m 1H, CH), 6.32 (d, $J=4.5 \mathrm{~Hz}, 1 \mathrm{H}$, Ar-H), 7.48 (dd, $J=1.5,6.0 \mathrm{~Hz}, 1 \mathrm{H}, \mathrm{Ar}-\mathrm{H}), 7.73$ (d, $J$ $=8.0 \mathrm{~Hz}, 1 \mathrm{H}, \mathrm{Ar}-\mathrm{H}), 8.49(\mathrm{dd}, J=0.5,7.0 \mathrm{~Hz}, 1 \mathrm{H}$, Ar-H), 8.54 (d, J=1.0 Hz, 1H, Ar-H), 8.76 (s, 1H, Ar$\mathrm{H}), 9.43$ (s, 1H, NH), 11.04 (s, 1H, NH), 11.68 (s, 1H, $\mathrm{OH}) .{ }^{13} \mathrm{C}$ NMR (DMSO-d 6 ): $\delta 8.31,14.72,111.18$, $113.33,116.77,125.50,128.41,136.64,143.37$, $149.48,153.47,163.43,170.58,173.46 . \mathrm{MS}$ (ESI): $299\left([\mathrm{M}+\mathrm{H}]^{+}, 70 \%\right)$; MS (ESI): $297\left([\mathrm{M}-\mathrm{H}]^{-}, 17 \%\right)$. HRMS (ESI) calcd for $\mathrm{C}_{15} \mathrm{H}_{15} \mathrm{~N}_{4} \mathrm{O}_{3}, 299.1144$ $\left([\mathrm{M}+\mathrm{H}]^{+}\right)$; found 299.1137 .

(f). 2-(Cyclopropanecarboxamido)-N-(4-iodopyridin3-yl)isonicotinamide (5): Compound 5 was prepared from compound $\mathbf{2}$ with 4-iodopyridin-3-amine using the same procedure as described for the synthesis of 4a as a yellow solid, yield 41\%. $R_{f}=0.70$ (1:9 $\mathrm{MeOH} / \mathrm{CH}_{2} \mathrm{Cl}_{2}$ ), mp 156-158 ${ }^{\circ} \mathrm{C}$. ${ }^{1} \mathrm{H}$ NMR (DMSO$\left.\mathrm{d}_{6}\right): \delta$ 0.81-0.85 (m, 4H, $\left.2 \times \mathrm{CH}_{2}\right), 2.02-2.08(\mathrm{~m}, 1 \mathrm{H}$, $\mathrm{CH}), 7.58(\mathrm{~d}, J=5.0 \mathrm{~Hz}, 1 \mathrm{H}, \mathrm{Ar}-\mathrm{H}), 8.07(\mathrm{~d}, J=5.0$ $\mathrm{Hz}, 1 \mathrm{H}, \mathrm{Ar}-\mathrm{H}), 8.12$ (d, J=5.0 Hz, 1H, Ar-H), 8.48 (s, $1 \mathrm{H}, \operatorname{Ar}-\mathrm{H}), 8.52(\mathrm{~d}, J=5.0 \mathrm{~Hz}, 1 \mathrm{H}, \operatorname{Ar}-\mathrm{H}), 8.60$ (s, 1H, Ar-H), 10.55 (s, 1H, NH), 11.01 (s, 1H, NH). MS (ESI): $409\left([\mathrm{M}+\mathrm{H}]^{+}, 100 \%\right)$; MS (ESI): 407 ([M-H] $]^{-}$ $100 \%)$.

(g). 2-(Cyclopropanecarboxamido)- $\mathrm{N}-(4-(4-$ methoxyphenyl)pyridin-3-yl)isonicotinamide (7a): To a suspension of compound 5 (82 $\mathrm{mg}, 0.2 \mathrm{mmol})$, (4methoxyphenyl)boronic acid (6a, $46 \mathrm{mg}, 0.3 \mathrm{mmol}$ ), and $\mathrm{Na}_{2} \mathrm{CO}_{3}(53 \mathrm{mg}, 0.5 \mathrm{mmol})$ in dioxane $(50 \mathrm{~mL})$ was added tetrakis(triphenylphosphine)palladium $(0)$ (23 $\mathrm{mg}, 0.02 \mathrm{mmol}$ ). The reaction mixture was subsequently heated at $110{ }^{\circ} \mathrm{C}$ for $15 \mathrm{~h}$. After the reaction was cooled down, it was filtered through Celite, washed with dioxane, and concentrated in vacuo. The resultant residue was purified by column chromatography on silica gel with eluent (2:98 $\mathrm{MeOH} / \mathrm{CH}_{2} \mathrm{Cl}_{2}$ ) to give a white solid product 7a (49 $\mathrm{mg}, 63 \%) . R_{f}=0.40\left(1: 19 \mathrm{MeOH} / \mathrm{CH}_{2} \mathrm{Cl}_{2}\right)$, mp 170$172{ }^{\circ} \mathrm{C} .{ }^{1} \mathrm{H}$ NMR $\left(\mathrm{CDCl}_{3}\right): \delta 0.91-0.95\left(\mathrm{~m}, 2 \mathrm{H}, \mathrm{CH}_{2}\right)$, 1.09-1.13 (m, 2H, $\left.\mathrm{CH}_{2}\right), 1.55-1.59(\mathrm{~m}, 1 \mathrm{H}, \mathrm{CH}), 3.88$ $\left(\mathrm{s}, 3 \mathrm{H}, \mathrm{OCH}_{3}\right), 7.08$ (dd, $\left.J=2.0,7.0 \mathrm{~Hz}, 2 \mathrm{H}, \mathrm{Ph}-\mathrm{H}\right)$, $7.23(\mathrm{~d}, J=5.0 \mathrm{~Hz}, 1 \mathrm{H}, \mathrm{Ar}-\mathrm{H}), 7.38(\mathrm{dd}, J=2.0,7.0$ $\mathrm{Hz}, 2 \mathrm{H}, \mathrm{Ph}-\mathrm{H}), 7.45$ (dd, $J=1.5,5.0 \mathrm{~Hz}, 1 \mathrm{H}, \mathrm{Ar}-\mathrm{H})$, $8.16(\mathrm{~s}, 1 \mathrm{H}, \mathrm{Ar}-\mathrm{H}), 8.37$ (d, $J=5.5 \mathrm{~Hz}, 1 \mathrm{H}, \mathrm{Ar}-\mathrm{H})$, 8.38 (s, 1H, Ar-H), 8.41 (s, 1H, NH), 8.47 (d, $J=5.0$ $\mathrm{Hz}, 1 \mathrm{H}, \mathrm{Ar}-\mathrm{H}), 9.59$ (s, 1H, NH); ${ }^{1} \mathrm{H}$ NMR (DMSO$\left.\mathrm{d}_{6}\right): \delta \quad 0.83-0.88\left(\mathrm{~m}, 4 \mathrm{H}, 2 \times \mathrm{CH}_{2}\right), 2.05-2.11(\mathrm{~m}, 1 \mathrm{H}$, $\mathrm{CH}), 3.80\left(\mathrm{~s}, 3 \mathrm{H}, \mathrm{OCH}_{3}\right), 7.03(\mathrm{~d}, J=7.5 \mathrm{~Hz}, 2 \mathrm{H}, \mathrm{Ph}-$ $\mathrm{H}), 7.43$ (d, J = 5.0 Hz, 1H, Ar-H), 7.47 (d, J=5.0 Hz, $1 \mathrm{H}, \mathrm{Ar}-\mathrm{H}), 7.49$ (d, J = 7.5 Hz, 2H, Ph-H), 8.48 (s, $2 \mathrm{H}, \mathrm{Ar}-\mathrm{H}), 8.55$ (d, $J=6.0 \mathrm{~Hz}, 1 \mathrm{H}, \mathrm{Ar}-\mathrm{H}), 8.63$ (s, 1H, Ar-H), 10.37 (s, 1H, NH), 11.00 (s, 1H, NH). MS (ESI): $389\left([\mathrm{M}+\mathrm{H}]^{+}, 100 \%\right)$; MS (ESI): $387\left([\mathrm{M}-\mathrm{H}]^{-}\right.$, $40 \%)$.

(h). 2-(Cyclopropanecarboxamido)- $\mathrm{N}-(4-(4-$ hydroxyphenyl)pyridin-3-yl)isonicotinamide (7b): Compound $\mathbf{7 b}$ was prepared using the same procedure as described for the synthesis of 7a by substituting (4hydroxyphenyl)boronic acid (6b) for $\mathbf{6 a}$ as a light blue solid, yield 48\%. $R_{f}=0.35\left(1: 16 \mathrm{MeOH} / \mathrm{CH}_{2} \mathrm{Cl}_{2}\right), \mathrm{mp}$ 163-165 ${ }^{\circ} \mathrm{C}$. ${ }^{1} \mathrm{H}$ NMR (DMSO-d ${ }_{6}$ ): $\delta$ 0.80-0.86 (m, $\left.4 \mathrm{H}, 2 \times \mathrm{CH}_{2}\right), 2.00-2.05(\mathrm{~m}, 1 \mathrm{H}, \mathrm{CH}), 6.80(\mathrm{~d}, J=$ $10.5 \mathrm{~Hz}, 2 \mathrm{H}, \mathrm{Ph}-\mathrm{H}), 7.34$ (d, $J=10.5 \mathrm{~Hz}, 2 \mathrm{H}, \mathrm{Ph}-\mathrm{H})$, 7.40 (s, 1H, Ar-H), 7.41 (s, 1H, Ar-H), 8.44 (d, J=6.5 $\mathrm{Hz}, 1 \mathrm{H}, \mathrm{Ar}-\mathrm{H}), 8.47$ (s, 1H, Ar-H), 9.49 (d, $J=6.5 \mathrm{~Hz}$, $1 \mathrm{H}, \mathrm{Ar}-\mathrm{H}), 8.56$ (s, 1H, Ar-H), $9.66(\mathrm{~s}, 1 \mathrm{H}, \mathrm{OH})$, $10.30(\mathrm{~s}, 1 \mathrm{H}, \mathrm{NH}), 10.95(\mathrm{~s}, 1 \mathrm{H}, \mathrm{NH}) .{ }^{13} \mathrm{C} \mathrm{NMR}$ $\left(\mathrm{DMSO}_{\mathrm{d}}\right): \delta$ 7.73, 14.18, 30.62, 111.54, 115.49, $116.61,124.11,126.83,129.49,130.68,143.35$, $145.46,147.86,148.47,149.47,152.74,157.82$, 164.90, 172.73. MS (ESI): $375\left([\mathrm{M}+\mathrm{H}]^{+}, 100 \%\right) ; \mathrm{MS}$ (ESI): 373 ([M-H] $\left.]^{-}, 80 \%\right)$. HRMS (ESI) calcd for $\mathrm{C}_{21} \mathrm{H}_{19} \mathrm{~N}_{4} \mathrm{O}_{3}, 375.1457\left([\mathrm{M}+\mathrm{H}]^{+}\right)$; found 375.1451.

(i) 2-(cyclopropanecarboxamido)- $\mathrm{N}$-(4$\left[{ }^{11}\right.$ C]methoxypyridin-3-yl)isonicotinamide $\quad\left(\left[{ }^{11} \mathrm{C}\right] 4 a\right)$ and 2-(cyclopropanecarboxamido)-N-(4-(4$\left[{ }^{11}\right.$ C]methoxyphenyl)pyridin-3-yl)isonicotinamide $\left(\left[{ }^{11} \mathrm{C}\right] 7 \mathrm{a}\right):\left[{ }^{11} \mathrm{C}\right] \mathrm{CO}_{2}$ was produced by the ${ }^{14} \mathrm{~N}(\mathrm{p}, \alpha){ }^{11} \mathrm{C}$ nuclear reaction in the small volume $\left(9.5 \mathrm{~cm}^{3}\right)$ aluminum gas target provided with the Siemens RDS111 Eclipse cyclotron. The target gas consisted of $1 \%$ oxygen in nitrogen purchased as a specialty gas from Praxair, Indianapolis, IN. Typical irradiations used for the development were $58 \mu \mathrm{A}$ beam current and $15 \mathrm{~min}$ on target. The production run produced approximately 25.9 $\mathrm{GBq}$ of $\left[{ }^{11} \mathrm{C}\right] \mathrm{CO}_{2}$ at EOB. The desmethyl precursor $\mathbf{4 b}$ or $7 \mathbf{b}(0.1-0.3 \mathrm{mg})$ was dissolved in $\mathrm{CH}_{3} \mathrm{CN}(300 \mu \mathrm{L})$. To this solution was added aqueous $\mathrm{NaOH}(2 \mathrm{~N}, 2 \mu \mathrm{L})$. The mixture was transferred to a small reaction vial. No-carrier-added (high specific activity) $\left[{ }^{11} \mathrm{C}\right] \mathrm{CH}_{3} \mathrm{OTf}$ that was produced by the gasphase production method ${ }^{27}$ within $12 \mathrm{~min}$ from $\left[{ }^{11} \mathrm{C}\right] \mathrm{CO}_{2}$ through $\left[{ }^{11} \mathrm{C}\right] \mathrm{CH}_{4}$ and $\left[{ }^{11} \mathrm{C}_{\mathrm{CH}_{3} \mathrm{Br}}\right.$ with silver triflate (AgOTf) column was passed into the reaction vial at $\mathrm{RT}$ until radioactivity reached a maximum ( $2 \mathrm{~min}$ ), and then the reaction vial was isolated and heated at $80{ }^{\circ} \mathrm{C}$ for $3 \mathrm{~min}$. The contents of the reaction vial were diluted with aqueous $\mathrm{NaHCO}_{3}$ $(0.1 \mathrm{M}, 1 \mathrm{~mL})$. The reaction vial was connected to a 3$\mathrm{mL}$ HPLC injection loop. The labeled product mixture 
solution was injected onto the semi-preparative HPLC column for purification. The product fraction was collected in a recovery vial containing $30 \mathrm{~mL}$ water. The diluted tracer solution was then passed through a C-18 Sep-Pak Light cartridge, and washed with water $(3 \times 10 \mathrm{~mL})$. The cartridge was eluted with $\mathrm{EtOH}(3 \times$ $0.4 \mathrm{~mL}$ ) to release the labeled product, followed by saline $(10-11 \mathrm{~mL})$. The eluted product was then sterile-filtered through a Millex-FG $0.2 \mu \mathrm{m}$ membrane into a sterile vial. Total radioactivity was assayed and total volume $(10-11 \mathrm{~mL})$ was noted for tracer dose dispensing. The overall synthesis time including HPLC-SPE purification and reformulation was $\sim 40$ min from EOB. The same procedure was used to prepare the target tracers $\left[{ }^{11} \mathrm{C}\right] \mathbf{4 a}$ and $\left[{ }^{11} \mathrm{C}\right] \mathbf{7 a}$ from their corresponding precursors $\mathbf{4 b}$ and $\mathbf{7 b}$. Retention times in the analytical HPLC system were: $t_{R} \mathbf{4 b}=$ $4.60 \mathrm{~min}, \mathrm{t}_{\mathrm{R}} \mathbf{4 a}=6.68 \mathrm{~min}, \mathrm{t}_{\mathrm{R}}\left[{ }^{11} \mathrm{C}\right] \mathbf{4 a}=6.73 \mathrm{~min}$; and $t_{R} 7 \mathbf{b}=3.23$ min, $t_{R} 7 \mathbf{a}=5.02 \mathrm{~min}, t_{R}\left[{ }^{11} \mathrm{C}\right] 7 \mathbf{a}=5.12$ min. Retention times in the preparative HPLC system were: $t_{R} 4 \mathbf{b}=7.70 \mathrm{~min}, \mathrm{t}_{\mathrm{R}} \mathbf{4 a}=10.58 \mathrm{~min}, \mathrm{t}_{\mathrm{R}}\left[{ }^{11} \mathrm{C}\right] \mathbf{4 a}=$ $10.65 \mathrm{~min}$; and $t_{R} 7 \mathbf{b}=4.56 \mathrm{~min}, \mathrm{t}_{\mathrm{R}} 7 \mathbf{a}=6.85 \mathrm{~min}, \mathrm{t}_{\mathrm{R}}$ $\left[{ }^{11} \mathrm{C}\right] 7 \mathbf{a}=6.93 \mathrm{~min}$. 